\title{
Diversity of parasites in Cichlasoma amazonarum Kullander, 1983 during rainy and dry seasons in eastern Amazon (Brazil)
}

\section{A. A. Carvalho ${ }^{1}$ | M. Tavares-Dias ${ }^{2}$}

${ }^{1}$ University of Amapá State (UEAP), Macapá, Brazil

${ }^{2}$ Embrapa Amapá, Macapá, Brazil

\section{Correspondence}

Marcos Tavares-Dias, Rodovia Juscelino Kubitschek, Macapá, AP, Brazil.

Email: marcos.tavares@embrapa.br

Funding information

Scientific Initiation Bursary, Grant/Award Number: 143468/2013-8; CNPq, Grant/

Award Number: 303013/2015-0

\begin{abstract}
Summary
This study investigated the influence of the rainy and dry seasons on the parasite communities of Cichlasoma amazonarum (Kullander, 1983) in a tributary of the Amazon River system, northern Brazil. Of 112 fish examined, 95.5\% were parasitized by Ichthyophthirius multifiliis, Piscinoodinium pillulare, Gussevia disparoides, Posthodiplostomum sp., Procamallanus (Spirocamallanus) inopinatus, and Echinorhynchus paranensis, as well as by the Glossiphoniidae leech. Ichthyophthirius multifiliis and P. pillulare were the dominant parasite species, with I. multifiliis the most prevalent and abundant; the leech (Glossiphoniidae) was the least prevalent and least abundant. Parasites presented an aggregate dispersion pattern and seasonal variations in infestation levels, influenced by the environmental conditions in the rainy season. Variation in the parasite dynamics created overall changes in the parasite communities, characterized by greater diversity, species richness and evenness during the rainy season. However, there was a high similarity (99.8\%) in the parasite community structure between the rainy and dry seasons. During the dry season the hosts had predominantly 1-3 parasite species compared to 3-4 parasites in the rainy season. Some parasites in the eastern Amazon undergo population changes relating to seasonality. These results thus indicate the correct season to apply adequate prophylactic measures to reduce negative impacts of parasites in this wild ornamental fish when captured.
\end{abstract}

\section{1 | INTRODUCTION}

Studies conducted in the eastern Amazon (Brazil) have indicated that the parasite communities of native cichlids do not present a diversity of species, but rather consist of a small number of specialist species (Neves, Pereira, Tavares-Dias, \& Luque, 2013; Tavares-Dias, Oliveira, Gonçalves, \& Silva, 2014). However, there have been few studies on the seasonal variations of the parasite community in native cichlids in the Amazon region (Neves et al., 2013; Tavares-Dias et al., 2014), even though this Neotropical region contains more than 180 species of these Cichliformes, some of which are endemic (Froese \& Pauly, 2016). Thus, the seasonal variation of the parasite prevalence and their abundance in Cichlasoma amazonarum Kullander, 1983 should be investigated.

Temperature can influence the immune system of the host fish and the reproduction rate of the parasites, given that innate immunity is more active at low temperatures while immunity of the adaptive system tends to be suppressed at low temperatures (Dias \& Tavares-Dias, 2015; Ondracková et al., 2015; Rohlenová et al., 2011). Therefore, in temperate climate regions, the seasonal temperature variations may alter not only the metabolism of the fish, but also the parasite communities in fish populations (Lamková, Šimková, Palíková, Jurajda, \& Lojek, 2007; Ondracková et al., 2015; Rohlenová et al., 2011). However, in regions with a tropical climate, it can be expected that the parasite communities will have a stable structure over the course of the year (Dias \& Tavares-Dias, 2015; Violante-González, Aguirre-Macedo, \& Rojas-Herrera, 2008). In the Amazon region, since the climate is one of tropical forest, the dynamics of rainfall levels may promote changes to the quality of the environment in the different ecosystems (Dias \& Tavares-Dias, 2015; Gonçalves, Oliveira, Neves, \& Tavares-Dias, 2016; Neves et al., 2013; Tavares-Dias et al., 2014). The rainy season lasts from December to May and the dry season from June to November 
(Souza \& Cunha, 2010), thus promoting changes to the Amazonian fish community and affecting some parasites (Dias \& Tavares-Dias, 2015; Gonçalves et al., 2016; Neves et al., 2013; Tavares-Dias et al., 2014).

Due to fishery of $C$. amazonarum and with gradual increase in the aquaculture of this fish, there is a need to determine the seasonal variation of their parasites. This is critical to assess the parasites' reproductive cycles and design adequate mitigation methods. We hypnotized that some parasite species vary during the rainy or dry season. Therefore, the parasite community and effects of seasons on the variability of the parasites in wild $\mathrm{C}$. amazonarum were studied during the rainy and dry seasons in a tributary of the Amazon River system in eastern Amazon, northern Brazil.

\section{2 | MATERIALS AND METHODS}

\section{1 | Study area}

This study was conducted at three points in the Igarapé Fortaleza basin $\left(00^{\circ} 00^{\prime} 56.3 \mathrm{~N} ; 051^{\circ} 05^{\prime} 27.1 \mathrm{~W}\right)$, a system formed by a main channel and rich swamps influenced by rainfall in the Amazon region and the tides of the Amazon River. Fish were caught at night using gill nets of different mesh sizes (15-35 mm). Regional vegetation consists of plants characteristic of floodplain forests and herbaceous fields that are periodically inundated, bringing in many species of macrophytes (Tavares-Dias et al., 2014; Thomaz, Costa-Neto, \& Tostes, 2004). The climate is typical for this tropical forest, with maximum rainfall rates from December to May and minimums from June to November (Souza $\&$ Cunha, 2010). Seasonality was therefore based on the rainy and dry seasons. This seasonality promotes a transition within the flooded system of the vegetation, land and water, thereby creating a very dynamic ecosystem. At the time of fish capture, the $\mathrm{pH}$, temperature and dissolved oxygen of the water were measured using digital devices appropriate for each purpose. The monthly rainfall rates were obtained from the Hydrometeorology and Renewable Energy Center (NHMET) of the Institute of Scientific and Technological Research of the State of Amapá (IEPA). From July 2011 to February 2013, the water quality data were measured once each month.

\section{2 | Fish and parasite sampling procedures}

From July 2011 to February 2013, 112 specimens of C. amazonarum were captured for parasitological analyses. Fish collected in the dry season measured $12.5 \pm 2.1 \mathrm{~cm}$ (range 8.2-18.9) total length and weighed $47.1 \pm 19 \mathrm{~g}$ (range 7.6-79.4); fish collected in the rainy season measured $12.6 \pm 1.3 \mathrm{~cm}$ (range 9.0-14.5) total length and weighed $54.3 \pm 16.5 \mathrm{~g}$ (range 24.0-108). All fish were conserved for 2-3 $\mathrm{hr}$ in ice and transported to the Laboratory for Aquatic Organism Health, at Embrapa Amapá. The mouth, opercula and gills of each necropsied fish were examined to detect the presence of ectoparasites, and the viscera and gastrointestinal tract were examined to detect endoparasites. Collection, fixation, counting, and preparation of parasites for identification were according to techniques described by Eiras, Takemoto, and Pavanelli (2006). Protozoan parasites were counted in a Sedgewick-Rafter chamber. The parasitological terms used are in accordance with Rohde, Hayward, and Heap (1995) and Bush, Lafferty, Lotz, and Shostak (1997).

\section{3 | Data analysis}

Descriptors for the constituent parasite community were calculated: (i) species richness; (ii) Brillouin diversity index (HB); (iii) evenness associated with the Brillouin diversity index (E); and (iv) Berger-Parker dominance index (d) (Magurran, 2004), using the Diversity software (Pisces Conservation Ltd, UK). Similarity in parasite community structure between the rainy and dry season was compared using two different distance indices: the Jaccard index (qualitative index), based on presence-absence data; and the quantitative Bray-Curtis index, based on parasites abundance (Ludwig \& Reynolds, 1988; Magurran, 2004). These similarity indices were determined using Past software (Paleontological Statistics version 3.0).

Differences in parasite prevalence between the rainy and dry seasons were evaluated using the chi-square test $\left(\chi^{2}\right)$ with Yates correction, and differences in abundance using the Mann-Whitney test (U). The Shapiro-Wilk test was used to determine whether the parasite abundance presented normal distribution. Spearman coefficient ( $r s$ ) was used to investigate the correlation of host length to abundance, species richness, $H B$ and $E$. Total length and weight of the host between dry and rainy seasons were compared using the $t$-test. Body weight $(\mathrm{g})$ and total length $(\mathrm{cm})$ were used to calculate the relative condition factor $(\mathrm{Kn})$ of the fish using the length-weight relationship $\left(W=a L^{b}\right)$ after logarithmic transformation of length and weight and subsequent adjustment of two straight lines, thus obtaining $\ln y=\ln A+B \ln x$ (Le-Cren, 1951). The relative condition factor values for the fish in the dry and rainy seasons were compared using the Mann-Whitney test (U) (Zar, 2010).

\section{3 | RESULTS}

During the rainy season, the mean water temperature was $29.5 \pm 0.3^{\circ} \mathrm{C} ; \mathrm{pH} 6.1 \pm 0.4$; dissolved oxygen $2.6 \pm 0.3 \mathrm{mg} / \mathrm{L}$ and rainfall $232.9 \pm 158.9 \mathrm{~mm}$. During the dry season, the mean water temperature was $30.5 \pm 0.3^{\circ} \mathrm{C} ; \mathrm{pH} \quad 6.3 \pm 0.3$; dissolved oxygen $2.0 \pm 0.3 \mathrm{mg} / \mathrm{L}$ and rainfall $88.6 \pm 100.6 \mathrm{~mm}$.

Among the $112 \mathrm{C}$. amazonarum specimens necropsied, all were parasitized by one or more species. A total of 1,273,499 parasites was collected, including Ichthyophthirius multifiliis, Piscinoodinium pillulare, Gussevia disparoides, Posthodiplostomum sp., Procamallanus (Spirocamallanus) inopinatus, Echinorhynchus paranensis and the leeches Glossiphoniidae gen. sp. The dominant species was I. multifiliis, and the constituent community was dominated by ectoparasite species.

Parasitism by P. (S.) inopinatus and E. paranensis showed no seasonal variation, with a low prevalence and abundance during both dry and rainy seasons. In contrast, the highest prevalence and abundance of G. disparoides and metacercariae of Posthodiplostomum sp. were during the rainy season. The highest prevalence of $P$. pillulare was 
TABLE 1 Differences in prevalence $(P)$ and mean abundance $(M A) \pm S D$ between seasons for parasites of Cichlasoma amazonarum, eastern Amazon, northern Brazil, July 2011 to February 2013

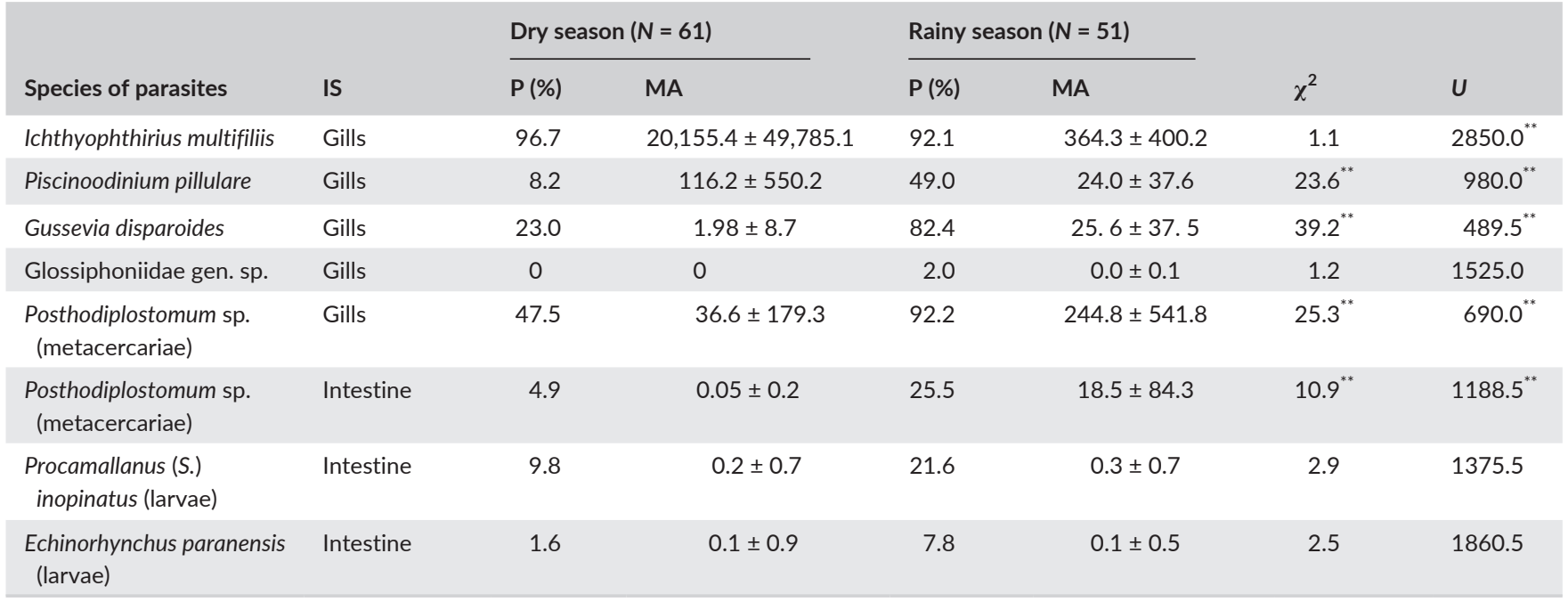

IS = infection site, $U=$ Mann-Whitney test, $\chi^{2}=$ chi-square test. ${ }^{* *} p<.001$.

TAB LE 2 Differences in diversity indices between seasons for parasites collected from Cichlasoma amazonarum, eastern Amazon, northern Brazil, July 2011 to February 2013

\begin{tabular}{lccrr} 
Diversity indices & Dry season $(N=61)$ & Rainy season $(N=51)$ & $U$ & $p$ \\
\hline Species richness & $1.9 \pm 1.0(1-5)$ & $3.7 \pm 1.0(2-7)$ & 353.0 & .001 \\
Brillouin $(H B)$ & $0.09 \pm 0.22(0.003-0.89)$ & $0.49 \pm 0.31(0.02-1.20)$ & 288.0 & .001 \\
\hline Evenness $(E)$ & $0.05 \pm 0.11(0-0.43)$ & $0.25 \pm 0.15(0.01-0.63)$ & 287.0 & .001 \\
Berger-Parker $(d)$ & $0.96 \pm 0.11(0.52-1.00)$ & $0.82 \pm 0.15(0.46-1.00)$ & 2783.0 & .001 \\
\hline
\end{tabular}

$U=$ Mann-Whitney test; $p=$ probability. Values in parentheses indicate range.

also during the rainy season, but with the highest intensity during the dry season; the highest prevalence of $I$. multifiliis was during the dry season. Glossiphoniidae species were leeches found at low levels of parasitism on the gills of $C$. amazonarum, and only in the rainy season (Table 1).

There was a variation in the parasitic diversity indices between the rainy and dry seasons, whereby the diversity index $(H B)$, evenness of diversity $(E)$ and parasite species richness had higher values during the rainy season. In contrast, the Berger-Parker dominance $(d)$ was higher during the dry season (Table 2).

Host length showed no correlation with parasite species richness ( $r s=.028, p=.771$ ), Brillouin diversity ( $r s=.060, p=.529$ ) or evenness ( $r s=.043, p=.653$ ). During the dry season, the hosts were predominantly infected by $1-3$ parasite species; during the rainy season, the hosts had predominantly 3-4 parasite species (Figure 1 ). The Jaccard index $(J=1.0)$ and Bray-Curtis dissimilarity $(B=0.17)$ showed a high similarity in the abundance of the parasite community between the rainy and dry seasons.

For the hosts, growth was allometrically negative $(b=1.6921$; $r^{2}=.813$ ), and body weight was positive in relation to total length $(r s=.872, p<.001)$. This negative allometric growth indicated that there was a greater increase in body weight than in size. However, the fish condition factor in the dry season was higher than in the rainy season, thus indicating different body conditions (Figure 2). In contrast, the weight of the host in the dry season was lower $(t=2.09$, $p=.039)$ than in the rainy season.

Abundance of $G$.disparoides presented a weak correlation with the length and weight of the host, as did the abundance of Posthodiplostomum sp. in the gills in relation to the length and weight of the host. In contrast, the abundance of Posthodiplostomum sp. in the intestine presented no correlation with length and weight of the host. The abundance of $I$. multifiliis, P. pillulare, and $P$. (S.) inopinatus showed no correlation with the length and weight of the host (Table 3 ).

\section{4 | DISCUSSION}

The parasite community of $C$. amazonarum consists mostly of ectoparasite species. In addition, the length of the host did not influence the richness of parasite species, Brillouin diversity index, or evenness, with the highest values occurring during the rainy season. The parasite community in cichlid Aequidens tetramerus in the same region as that of the present study was composed predominately of ectoparasites species, presenting greater richness of species, diversity and evenness during the dry season (Tavares-Dias et al., 2014). In contrast, Cichlasoma trimaculatum in a lake in Mexico had a parasite community composed 


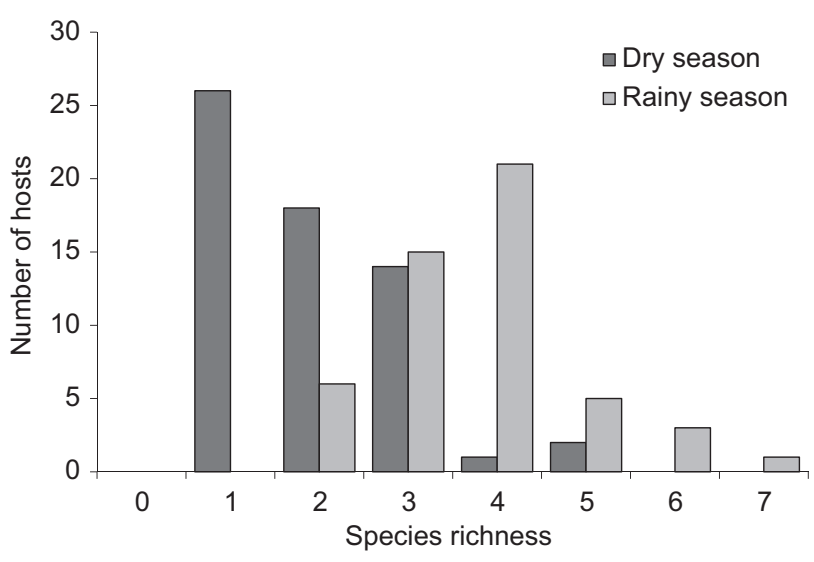

FIGURE 1 Species richness of Cichlasoma amazonarum parasites during dry and rainy seasons, eastern Amazon, northern Brazil, July 2011 to February 2013

TABLE 3 Spearman correlation coefficient ( $r s$ ) of Cichlasoma amazonarum parasite abundance as to length and weight, eastern Amazon, northern Brazil, July 2011 to February 2013

\begin{tabular}{|c|c|c|c|c|}
\hline \multirow{2}{*}{$\begin{array}{l}\text { Body parameters } \\
\text { Parasite species }\end{array}$} & \multicolumn{2}{|c|}{ Total length } & \multicolumn{2}{|c|}{ Body weight } \\
\hline & rs & $p$ & rs & $p$ \\
\hline Ichthyophthirius multifiliis & .166 & .081 & .169 & .169 \\
\hline Piscinoodinium pillulare & .045 & .639 & -.159 & .094 \\
\hline Gussevia disparoides & -.211 & .025 & -.217 & .021 \\
\hline Posthodiplostomum sp. & -.226 & .016 & -.324 & .0005 \\
\hline $\begin{array}{l}\text { Procamallanus (S.) } \\
\text { inopinatus }\end{array}$ & -.050 & .596 & .009 & .923 \\
\hline
\end{tabular}

predominately of endoparasite species, with greater parasite richness and diversity during the rainy season (Violante-González et al., 2008). The parasitic communities are influenced by various biotic and abiotic factors (Dias \& Tavares-Dias, 2015; Ondracková et al., 2015; Rohlenová et al., 2011); hence, they can cause differences among different fish populations. Seasonal variations in parasite communities have been usually correlated with environmental changes. In a given parasite community, some species undergo substantial changes relating to seasonality, while others do not. This has been explained primarily by parasite life cycles, environmental dynamics and host-specific immune responses (Lamková et al., 2007; Neves et al., 2013; Ondracková et al., 2015; Tavares-Dias et al., 2014; Violante-González et al., 2008).

The C. amazonarum parasite community presented only one specialist parasite: the G. disparoides; the component community presented the same pattern in this cichlid, i.e. with a highly dominant species and little diversity. Cichlasoma amazonarum feeds on aquatic plants, seeds, insects and detritus (Soares et al., 2011), but its omnivorous diet also includes small invertebrates (microcrustaceans and mollusks), as indicated in this study. The endoparasite communities, which are trophically transmitted parasites, indicate that this host consumed a low diversity of prey in the studied habitat, which suffers from an urban anthropogenic eutrophication that is greater during the dry season (Gonçalves et al., 2016; Takyama, Silva, Costa, \& Nascimento,

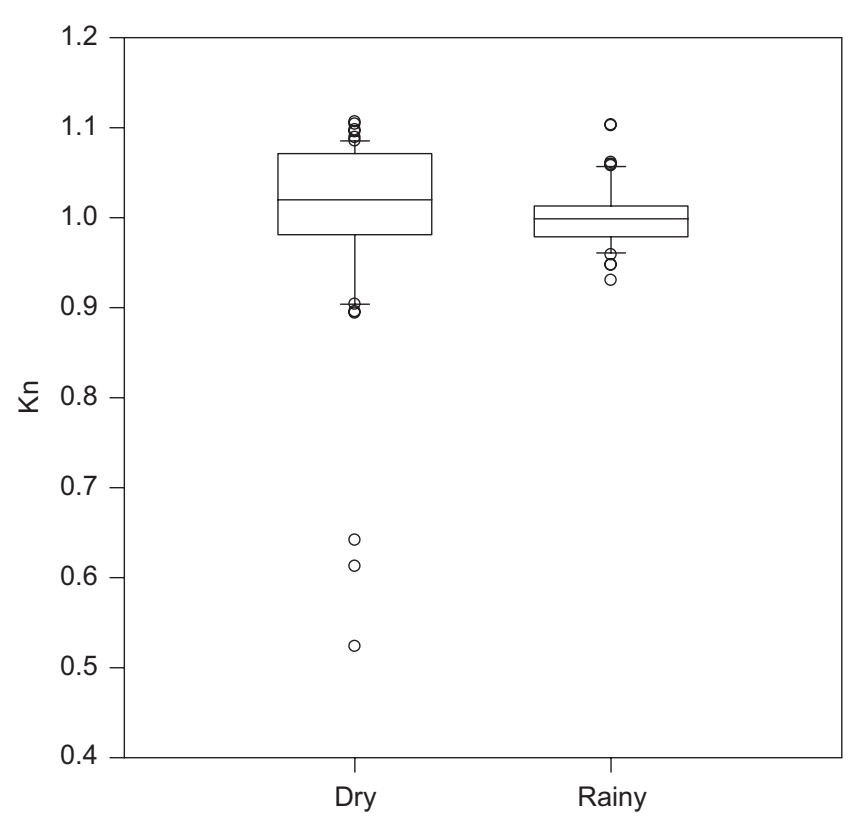

FIGURE 2 Relative condition factor (Kn) for Cichlasoma amazonarum, eastern Amazon, northern Brazil, July 2011 to February 2013. Box plots represent medians, interquartile ranges, minimummaximum ranges and outliers. Different mean values between dry $(n=61)$ and rainy $(n=51)$ season according to the Mann-Whitney test $(U=1886.0, p=.033)$

2004; Tavares-Dias et al., 2014). This may have an effect on the parasite community.

In the Amazon region, seasonality is strongly influenced by the rainy and dry seasons. In C. amazonarum there was a high similarity (almost 100\%) in the parasite community structure between the rainy and dry seasons; one of the factors influencing the parasites might be the level of rainfall. The prevalence of $P$. pillulare in $C$. amazonarum was highest in the rainy season, while abundance was higher in the dry season. In addition, I. multifiliis, the most prevalent and dominant parasite, occurred during both the rainy and dry seasons, but its abundance was greater during the rainy season. The high abundance of $I$. multifiliis during the dry season is due to low environmental quality, which seems to affect different hosts differently over the course of time. In addition, there were higher levels of parasitism due to G. disparoides in C. amazonarum during the rainy season, when the environmental quality was better. Similar studies focusing on directly transmitted parasites have also reported a relationship between prevalence and abundance of ectoparasites in the dry/rainy season cycle in the Amazon (Gonçalves et al., 2016; Neves et al., 2013; Tavares-Dias et al., 2014). However, other factors may also affect the prevalence and abundance of parasites in host fish populations. Thus, further studies are necessary, as we need to have a more comprehensive sampling strategy and with a larger sample size to be able to know how these parameters affect the parasite load in terms of reproduction, sex and age of $C$. amazonarum and in interaction with others factors, e.g. the temporal variation.

The dynamics of the process of recruitment of Posthodiplostomum sp. in mollusks and maintenance of metacercariae populations in the intermediate and definitive hosts possibly vary with the Amazonian 
seasonal cycle (Gonçalves et al., 2016; Neves et al., 2013). However, in C. amazonarum, there were higher parasitic levels of metacercariae of Posthodiplostomum during the rainy season. In addition, the highest parasitic levels of this digenean were found mainly in smaller fish. Therefore, because these infestations come into direct contact with cercariae of Posthodiplostomum sp., the hydrological cycle, hosts' feeding pattern and seasonal availability of the infectious stages of parasites in the environment were determining factors for the seasonal variations of these endoparasites. Environmental conditions may also play an important role in determining seasonal variation in prevalence and abundance of digeneans (Gonçalves et al., 2016; ViolanteGonzález et al., 2008). Moreover, this first report of E. paranensis in C. amazonarum showed low parasitic levels of this acanthocephalan, and thus had no effect in the dry and rainy seasons. These low levels of parasitism caused by E. paranensis larvae and adults in both seasons indicate that C. amazonarum is a paratenic host for this acanthocephalan, with an unknown life cycle.

In C. amazonarum, parasitic levels of $P$. (S) inopinatus were low, occurring in both the rainy and dry seasons. Such results therefore indicate the frequent presence of chironomids infected with $P$. (S) inopinatus, once these invertebrates are intermediate hosts to this nematode species (Hoshino \& Tavares-Dias, 2014), with C. amazonarum as the definitive host. Low parasitism by $P$. $(S)$ inopinatus during the dry and rainy seasons probably resulted from the environmental fluctuations in the Igarapé Fortaleza basin, which did not favor their transmission process, since this nematode has a short life cycle. Leeches were found at low levels of parasitism on the gills of $C$. amazonarum and only in the rainy season. Similar findings have also been reported for Hoplias malabaricus from the Brazilian Amazon (Gonçalves et al., 2016).

The length-weight relationship in C.amazonarum showed that weight did not increase proportionately to the increase in the length of the host; body size explained less than $35 \%$ of variance on parasite abundance. In addition, the condition factor was higher during the dry season. However, the $C$. amazonarum weight was higher during the rainy season, when the fish had greater access to food containing infective stages of the endoparasites. This thus indicates that fish with greater weights can tolerate higher levels of parasitism. In contrast, the seasonal variation of endoparasites and ectoparasites did not affect the condition factor of other fish populations of the eastern Amazon (Gonçalves et al., 2016; Tavares-Dias et al., 2014). Such differences between hosts in response to the condition factor may be attributed to different transmission strategies used by the different parasites (Gonçalves et al., 2016).

In summary, this first study on parasites of wild C. amazonarum populations indicated that the Amazonian hydrological cycle, host feeding behavior, and seasonal availability of the infectious stages of the parasites were determining factors for seasonal variations of the endoparasites. Furthermore, this study corroborates previous observations that some parasites undergo changes relating to seasonality, while others do not. For this wild fish population, a study on the seasonal dynamics of the parasite community might provide supporting knowledge for use in fishing and fish farming. This study may be of help in the holding facilities of this ornamental fish, to better understand the parasites dynamics. Finally, this information is useful for preventive programs involved with disease control and in indicating the correct season for applying prophylactic measures to reduce the negative impact(s) of parasites in captured fish.

\section{ACKNOWLEDGEMENTS}

Thanks to the Conselho Nacional de Pesquisa e Desenvolvimento Tecnológico (CNPq, Brazil) for the Scientific Initiation Bursary granted to first author (\#143468/2013-8). Dr. M. Tavares-Dias was supported by a research fellowship from CNPq (303013/2015-0).

\section{REFERENCES}

Bush, A. O., Lafferty, K. D., Lotz, J. M., \& Shostak, W. (1997). Parasitology meets ecology on its own terms: Margolis et al. revisited. Journal of Parasitology, 83, 575-583.

Dias, M. K. R., \& Tavares-Dias, M. (2015). Seasonality affects the parasitism levels in two fish species in the eastern Amazon region. Journal of Applied Ichthyology, 31, 1049-1055.

Eiras, J. C., Takemoto, R. M., \& Pavanelli, G. C. (2006). Métodos de estudos e técnicas laboratoriais em parasitologia de peixes [Methods of laboratory study and techniques in fish parasitology] (pp. 1-199). Maringá: Ed. Eduem.

Froese, R., \& Pauly, D. (Eds.) (2016). FishBase: World wide web electronic publication version (6/2016). Retrieved from http://www.fishbase.org.

Gonçalves, R. A., Oliveira, M. S. B., Neves, L. R., \& Tavares-Dias, M. (2016). Seasonal pattern in parasite infracommunities of Hoplerythrinus unitaeniatus and Hoplias malabaricus (Actinopterygii: Erythrinidae) from the Brazilian Amazon. Acta Parasitologica, 61, 119-129.

Hoshino, M. D. F. G., \& Tavares-Dias, M. (2014). Ecology of parasites of Metynnis lippincottianus (Characiformes: Serrasalmidae) from the eastern Amazon region, Macapá, State of Amapá, Brazil. Acta Scientiarum Biological Sciences, 36, 249-255.

Lamková, K., Šimková, A., Palíková, M., Jurajda, P., \& Lojek, A. (2007). Seasonal changes of immunocompetence and parasitism in chub (Leuciscus cephalus), a freshwater cyprinid fish. Parasitology Research, 101, 775-789.

Le-Cren, E. D. (1951). The length-weight relationship and seasonal cycle in gonadal weight and condition in the perch (Perca fluviatilis). Journal of Animal Ecology, 20, 201-219.

Ludwig, J. A. \& Reynolds, J. F. (1988). Statistical ecology: A primer on methods and computing (pp. 1-337). New York, NY: Wiley-Interscience Pub.

Magurran, A. E. (2004). Measuring biological diversity (pp. 1-25). Oxford, UK: Blackwell Science.

Neves, L. R., Pereira, F. B., Tavares-Dias, M., \& Luque, J. L. (2013). Seasonal Influence on the parasite fauna of a wild population of Astronotus ocellatus (Perciformes: Cichlidae) from the Brazilian Amazon. Journal of Parasitology, 99, 718-721.

Ondracková, M., Valová, Z., Hudcová, I., Michálková, V., Simková, A., Borcherding, J., \& Jurajda, P. (2015). Temporal effects on host-parasite associations in four naturalized goby species living in sympatry. Hydrobiologia, 746, 233-243.

Rohde, K., Hayward, C., \& Heap, M. (1995). Aspects of the ecology of metazoan ectoparasites of marine fishes. The Journal of Parasitology, 25, 945-970.

Rohlenová, K., Morand, S., Hyršl, P., Tolarová, S., Flajšhans, M., \& Šimková, A. (2011). Are fish immune systems really affected by parasites? An immunoecological study of common carp (Cyprinus carpio). Parasites \& Vectors, 4, 1-18.

Soares, M. G. M., Costa, E. L., Siqueira-Souza, F. K., Anjos, H. D. B., Yamamoto, K. C., \& Freitas, C. E. C. (2011). Peixes de lagos do médio Rio Solimões (2a ed., pp. 1-169). Manaus: Instituto Piatam. 
Souza, E. B., \& Cunha, A. C. (2010). Climatologia de precipitação no estado do Amapá e mecanismos climáticos de grande escala [Precipitation climatology in the state of Amapá and climatic mechanisms on a large scale]. In A. C. Cunha, E. B. Souza \& H. F. A. Cunha (Eds.), Tempo, clima e recursos hídricos: resultados do Projeto REMETAP no estado do Amapá [Weather, climate and water resources: Results of REMETAP Project in Amapá State] (pp. 177-195). Macapá: IEPA.

Takyama, L. R., Silva, A. Q., Costa, W. J. P., \& Nascimento, H. S. (2004). Qualidade das águas das ressacas das bacias do Igarapé da Fortaleza e do Rio Curiaú. In L. R. Takiyama \& A. Q. Silva (Eds.), Diagnóstico das ressacas do estado do Amapá: bacias do lgarapé da Fortaleza e Rio Curiaú, Macapá-AP (pp. 99-121). Macapá: GEA/SETEC/IEPA.

Tavares-Dias, M., Oliveira, M. S. B., Gonçalves, R., \& Silva, L. M. A. (2014). Ecology and seasonal variation of parasites in wild Aequidens tetramerus, a Cichlidae from the Amazon. Acta Parasitologica, 54, 158-164.

Thomaz, D. O., Costa-Neto, S. V., \& Tostes, L. C. L. (2004). Inventário florístico das ressacas das bacias do Igarapé da Fortaleza e do Rio Curiaú. In L. R. Takiyama \& A. Q. Silva (Eds.), Diagnóstico das ressacas do estado do Amapá: bacias do Igarapé da Fortaleza e Rio Curiaú, Macapá-AP (pp. 13-25). Macapá: GEA/SETEC/IEPA.

Violante-González, J., Aguirre-Macedo, M. L., \& Rojas-Herrera, A. (2008). Comunidad de parásitos metazoarios de la charra Cichlasoma trimaculatum en la laguna de Tres Palos, Guerrero, México. Revista Mexicana de Biodiversidad, 79, 405-412.

Zar, J. H. (2010). Biostatistical analysis (5th ed., pp. 1-944). New Jersey: Prentice Hall.

How to cite this article: Carvalho AA, Tavares-Dias $M$.

Diversity of parasites in Cichlasoma amazonarum Kullander, 1983 during rainy and dry seasons in eastern Amazon (Brazil).

J Appl Ichthyol. 2017;00:1-6. https://doi.org/10.1111/ jai.13451 